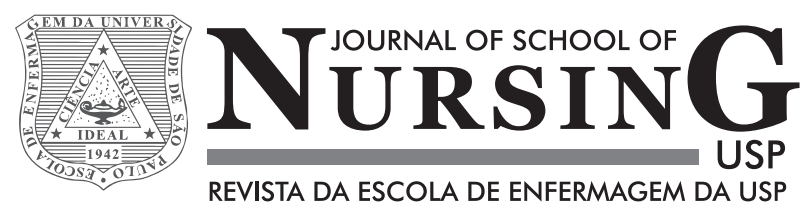

\title{
Analysis of suffering at work in Family Health Support Centers*
}

\author{
Análise do sofrimento no trabalho em Núcleos de Apoio à Saúde da Família \\ Análisis del sufrimiento en el trabajo en Núcleos de Apoyo a la Salud de la Familia
}

Débora Dupas Gonçalves do Nascimento ${ }^{1}$, Maria Amélia de Campos Oliveira ${ }^{2}$

How to cite this article:

Nascimento DDG, Oliveira MAC. Analysis of suffering at work in Family Health Support Centers. Rev Esc Enferm USP. 2016;(50):846-852. DOI: http://dx.doi. org/10.1590/S0080-623420160000600019

\footnotetext{
*Extracted from the thesis "O cotidiano de trabalho no NASF: percepções de sofrimento e prazer na perspectiva da Psicodinâmica do Trabalho", Programa Interunidades de Doutoramento em Enfermagem, Escola de Enfermagem de São Paulo, Escola de Enfermagem de Ribeirão Preto, Universidade de São Paulo, 2015.

${ }^{1}$ Fundação Oswaldo Cruz, Campo Grande, MS, Brazil.

${ }^{2}$ Universidade de São Paulo, Escola de Enfermagem, Departamento de Enfermagem em Saúde Coletiva, São Paulo, SP Brazil.
}

\begin{abstract}
Objective: Analyzing the work process in the Family Health Support Center. Method: An exploratory, descriptive case study using a qualitative approach. Focus groups were conducted with 20 workers of a Family Health Support Center, and the empirical material was subjected to content analysis technique and analyzed in light of Work Psychodynamics. Results: The category of suffering is presented herein as arising from the dialectical contradiction between actual work and prescribed work, from resistance to the Family Health Support Center's proposal and a lack of understanding of their role; due to an immediatist and curative culture of the users and the Family Health Strategy; of the profile, overload and identification with work. Conclusion: The dialectical contradiction between expectations from Family Health Strategy teams and the work in the Family Health Support Center compromises its execution and creates suffering for workers.
\end{abstract}

\section{DESCRIPTORS}

Family Health Strategy; Health Personnel; Work; Psychological Stress; Quality of Life. 


\section{INTRODUCTION}

The Family Health Support Center (NASF - Núcleo de Apoio à Saúde da Família) was established in the context of Primary Care (PC) in 2008 to qualify and expand the repertory of actions of the Family Health Strategy (FHS) teams through matricial support ${ }^{(1)}$. It aims at building attention and care networks, contributing to the full attainment of comprehensive care to SUS (Sistema Único de Saúde) users ${ }^{(2)}$. For this, it has its action based on teamwork - considering the complexity of the needs and current health problems and the interdependence of health work ${ }^{(3)}$ - using counterhegemonic tools, from the perspective of an expanded practice as a singular therapeutic project and the health project of the territory, still uncommon in the daily lives of health professionals, and especially from the FHS.

Its implementation has enabled advances in the production of care by FHS teams due to its great potential for mobilizing qualifying interventions as part of $\mathrm{PC}$, in addition to expanding access, local resolution of some cases and a consequent reduction in referrals to other health care network services (HCN - healthcare network). However, after nearly a decade since its implementation, several difficulties are being experienced by its employees, ranging from the lack of clarity about their role in the routine of FHS to the lack of tools to assess, evaluate and monitor the effectiveness and resolution of their work process. "This is a recent proposal in the context of public policies and one that offers tools and innovative forms of work organization, not relying on fully defined and systematic work processes"(4).

The lack of understanding of the NASF proposal by all those involved in the work process - managers, FHS professionals and users - can be translated into overload and demands of the workers with demands that are not able to be met as a result of the proposed work model. The effort from NASF professionals for this model to be understood, accepted and made effective according to its premises, as expressed in decrees and ministerial publications ${ }^{(1-2,5-6)}$, also results in stress and suffering to the workers, negatively reflecting on professional performance, efficiency and quality of work life, in addition to bringing repercussions to their personal lives.

This study aims to analyze the work process in the Family Health Support Center and the perceptions of professionals regarding stressful situations that cause suffering at work.

\section{METHOD}

An exploratory and descriptive study using a qualitative approach was conducted anchored in the theoretical and methodological framework of Collective Health and dialectical hermeneutics, seeking to find the meaning within a particular group in time and culture, interpreting the person that understands and what is understood ${ }^{(7)}$. The choice for Hermeneutic-Dialectical Method was due to the need for understanding the meaning of working in the NASF, as well as understanding stress and suffering which can compromise the quality of life of professionals working in this area.
The chosen method was the case study and theoretical framework of Work Psychodynamics by Dejours, which was adopted to address the process and the organization of work, identifying situations that cause stress and suffering as it seeks to analyze the "intersubjective processes mobilized by work situations" from understanding how employees feel and experience, and also the existing gap between prescribed work and real work ${ }^{(8)}$.

The study was conducted in a Social Health Organization (SHO) in the eastern region of São Paulo and it involved 20 workers from a NASF who participated in three focus groups between June and August 2014. Group 1 (G1) consisted of eight professionals and groups 2 and 3 (G2 and G3) had six professionals in each.

Content analysis was used for treating the empirical material resulting from the transcription recordings of the focus groups ${ }^{(9)}$. Core meanings were constructed resulting from identifying the central ideas in the speeches ${ }^{(7)}$.

The study met the requirements of Resolution No. 466/12 of the National Health Council for research on human beings. It was approved by the Research Ethics Committee of the USP Escola de Enfermagem under opinion No. 205.892 and by the Municipal Health Secretariat of São Paulo under the opinion No. 597.535-0 (CAAE 08751212.0.3001.0086). The subjects were informed about the research objectives and expressed their agreement to participate by signing the Clear and Informed Consent Form.

\section{RESULTS}

Analysis of the resulting material from the focus groups through the analytical category suffering at work, present in the theoretical framework of Work Psychodynamics allowed for identifying six units of meaning: 1) actual work versus prescribed work: resistance to the NASF proposal and a lack of understanding their role; 2) the immediatist and curative culture of FHS users; 3) profile, overload and identification of work; 4) interpersonal relationships and teamwork; 5) the feeling of not belonging and the lack of infrastructure; 6) violence and vulnerability in the area. This article will discuss the first three and the remaining three will be the subject of a subsequent publication.

\section{ACTUAL WORK VERSUS PRESCRIBED WORK: RESISTANCE TO THE NASF PROPOSAL AND A LACK OF UNDERSTANDING} THEIR ROLE

The dichotomy between real and prescribed work regarding team/staff dynamics and the functioning of health services is due to numerous intrinsic conditions, such as the resistance of the FHS to the NASF proposal and a lack of understanding their role, as well as extrinsic conditions such as work overload of FHS and a lack of an articulated health care network.

Moreover, from the perspective of the professionals, the NASF carries a proposal in its premise that is too innovative for the current overloaded reality of the FHS, thus resulting in difficulties in its implementation. These issues are 
sources of stress, wearing out and suffering that affect work development and the execution of the NASF proposal.

I think this model is too innovative for the reality of the health system that we have today. So it goes in parallel, and not at the same pace. We keep trying to pull it to one side and it keeps shifting to the other, and this causes wearing out (...) (G1).

Due to the great demand of cases and complaints, the desire for the NASF to become resolute in an eminently assistential and ambulatory perspective in order to overcome deficiency from the HCN and the FHS is one of the main causes of suffering at work.

(...) because in fact I think that the NASF was created to cover a huge hole of so many things that are lacking in outpatient care, in specialized medical care, which we do not have, and then the NASF is like - 'Oh, NASF will solve it!' And there's no way, because it is something totally schizophrenic. The proposal is that we offer support, but people expect us to give assistance, right? (...) (G3).

Matricial support and the joint management of cases potentiating strategies of health care - are little used on a daily basis by the FHS, as the most complex cases are not shared in a co-responsible manner or with joint interventions between FHS and NASF. These cases are often delegated to NASF, which has the mission of "putting out fires" as the FHS "delegates the case" in team meetings.

(...) there is little co-responsibility of the teams in the cases that are discussed. Then, the cases come in and the more complex ones are left to NASF, right? It is not a case that is to be worked together and: - 'Oh! It's gonna take a while? Is it going to take long for you to go there? 'This pressure, this demand, especially of the most difficult cases... We need a joint effort and shared actions, but it is all delegated to NASF (G1).

Another strongly evident dichotomy from the speeches concerns the NASF model in contrast to what is developed by FHS regarding the amount of consultations and health actions developed in different territories versus its quality. It is difficult to assess the qualitative interventions on a regular basis in health practice, since the evaluation and monitoring instruments historically used by management are focused on quantity and not quality.

(...) what are they going to demand from a team that has the obligation to perform qualitative work, to broaden perspectives about the individual and all, but that are going to be assessed quantitatively? (...) They will see the numbers, but it is a little incoherent (...). Then, what is assessed is different from what keeps us working... because it is the small things that give us hope and that motivate us to do more, to do things differently, to try to do it again (G1).

Suffering, demotivation and the nearly daily struggle of NASF workers confronting the resistances to accomplish their work model and to be recognized in face of the difficulties in understanding and the attempts to distort their role of support team are hereby explicit.

I repeat what the NASF does at least three or four times per week. If I do not repeat it at the meeting with the FHS, I repeat it with my own team or in a specific or shared service in which
I probably have to explain to the user what I will not be able to provide to them (...). And this affects the expectations of other people and it is very tiring and frustrating for the job (G3).

\section{THE IMMEDIATIST AND CURATIVE CULTURE OF FHS USERS}

The immediacy and curative culture is strongly present in health services and in professional practices. The desire for scheduled appointments in order to "resolve" the situation and the little appreciation of preventive actions and actions for health promotion are evident. This context creates frustration, as one of the NASF challenges is to end the cycle of this culture among managers, FHS teams and users.

(...) I see that we lack some of that; the FHS could offer a lot more promotion, but instead it is always remediating, remediating, putting bandages on life's problems and the actions are lacking. Then I see that it is lacking (...) (G1).

(...) we come from a cultural background of complaint-conduct for many years, a long time, this is national. And changing the head of the entire population or even of some technicians is difficult, so we will have to continue. If I've said it ten times, I will have to say it eleven, a thousand, I will have to say it a thousand and one times, right? It's tiring, it is stressful (...) (G2).

\section{Profile, overload and identification With WORK}

It was possible to identify suffering and burden, manifested by NASF workers due to the lack of a profile, as well as the actuation time in the NASF, which seems "to have an expiration date". Moreover, the identification with the work is what encourages NASF professionals to remain fighting for its implementation - even facing exhaustion and suffering.

I wonder about the profile of those who come in, because it's a matter of attitude, this matters a lot more than knowledge itself, right? I think that the fact that person has this determination, this energy, this drive, it becomes a very great differential (...) (G2).

Sometimes I say, I comment that the people who work in the $N A S F$ have an expiration date, because there comes a time that you've had to hit the same key so many times, you've had to insist so much that you lose hope; and when you lose hope that's it, it is impossible, you can't go any further... you'll have to invest yourself in something else (G2).

The turnover of professionals, the differences in workload due to different working hours, the excessive bureaucratic and administrative tasks all negatively influence the quality of working life of employees.

(...) so many people came and went, many left because of suffering, others left loving it but because they couldn't stand it (G1).

The difference in the quality of life of those working 20, 30 or 40 hours also influences a lot. It's a very heavy emotional burden for those working 40 bours (...) (G1).

(...) then you need to sit down, discuss, you have to pull all the time, you have to write down everything you do ... transcribe 
everything that you do into the medical records, think about what you are going to say, how you are going to say it. I think this is the most stressful part (G2).

The workload also arises from the high demand of cases, especially of mental health, tied to the low level of commitment and co-responsibility of the FHS with cases that do not need to be referred to other $\mathrm{HCN}$ services. In relation to the medical professionals, this issue may be related to their profile and also to training.

(...) in relation to doctors, it is the training that bothers me a lot. The doctor is not trained to work in a health care facility (...). For example, a mental health patient, right? How are you going to talk to a doctor about a mental health patient? - 'The patient cried and I would like him to see a psychologist.' And he/she does a referral for them to see to a psychiatrist. They cannot even start thinking of a medication. You cannot say - 'Oh, I'm not a psychiatrist, I will not prescribe a medication ...'Theoretically, in their training, they have this ability, they do but they are not willing to do it (...) (G3).

The suffering and overload identified are in favor of the need for institutional spaces that guarantee care and attention to workers' health.

(...) currently the work process is what bothers me, I think what really needs improving is caring for the caregiver. In fact, I think it is necessary, right? We are always caring for others (...) and there is no one to care for us, which makes it so all professionals get sick (...). We are in Primary Care, but we do not have any prevention or promotion for us either, especially regarding mental health (...) (G3).

\section{DISCUSSION}

The results revealed many challenges experienced by NASF workers in everyday work and suffering emerges in various everyday situations, sometimes related to FHS, sometimes to the NASF team itself.

In the daily practice, many unforeseen situations that are beyond what is prescribed occur. The situation is aggravated by the diversity and scope of the work in the NASF, not only by the issues regarding work organization and characteristics of the territorial context, but also due to its counter-hegemonic policies and actions, which have yet to prove themselves right in the context of health work. That is why this gap between actual and prescribed work happens, both regarding the profile of the professionals, the organization of work and the expectations that do not coincide with FHS in relation to NASF, the care needs of the population or the purposes of management. This demonstrates that work processes need to be reviewed, given the interdependence between the work of FHS and $\mathrm{NASF}^{(4)}$.

The excessive number of families, the substantial care demand, the turnover of professionals and the lack of support from HCN are limiting the possibilities of FHS, and therefore health care remains biologistic, curative, and based on individual programmatic actions that aim to fulfill numerical goals, which opposes the premises of NASF, creating resistance by professionals from FHS and the users to the NASF proposal even stronger and hindering the understanding of its role.

This disconnection between FHS and NASF, which is considered a 'very innovative model for the reality of the health system' and the lack of understanding of its role are perpetuated to this day, to a lesser extent and depending on the context, which makes workers have to restate 'what is it that the NASF does' so many times in order to justify themselves before the demands of FHS teams. This contributes to the gap between the workers and the limited effectiveness of the idealized purposes for NASF as a matricial support team to FHS.

These situations generate feelings of anxiety, fatigue and stress that result in suffering, which emerge due to the versatile expectation of NASF workers for solving the most complex cases. In addition, it compromises the professional identity of the worker due to a lack of recognition for the social relevance of their work since, in the perspective of Work Psychodynamics, it is from the view point of another that workers are constituted as subjects and build their individual and social identity ${ }^{(8)}$.

This almost daily struggle is evident in the workers' speeches and also in another study on NASF implementation and work process conducted in the country, which corroborates the results of this study with regard to lack of understanding, including from NASF workers themselves, of their supporting role ${ }^{(10)}$.

The role of NASF was also discussed in another study conducted in the municipality of São Paulo, which highlighted enhancing PC's ability to solve problems among its functions and help in the reorganization of $\mathrm{HCN}$, reviewing and optimizing reference flows and counter flows ${ }^{(11)}$ such as foreseen in Ordinances No. 154 and in 2488 concerning the implementation of NASF and the guidelines of $\mathrm{PC}$ and FHS, respectively ${ }^{(2,12)}$.

The influence of initial training on the profile of NASF workers also contributes to the suffering, as some professionals have little familiarity with PC due to singular professional training processes and being focused on a specialization.

The ethical and professional commitment of NASF workers to their work process is related to expanding the vision and the possibilities of intervention through empowerment of FHS teams from the perspective of matricial support and also of the user, aiming at an interdisciplinary and perhaps one day, a transdisciplinary approach. In the everyday reality of work in the FHS, "for an extended care to be available, it does not seem necessary nor feasible that a person or family needs to be compulsorily assisted by all kinds of practitioners of the FHS. Inter-professional work with knowledge integration and collaboration among health workers implies a certain number of shared practices, enhancing professional performance"(13).

However, from the analyzed context, it became clear that there were difficulties in sharing FHS cases under a co-responsibility perspective and understanding the NASF as a support role, as the tendency of 'passing the case' is quite common and often the responsibility for a particular health 
intervention falls on the NASF professional, similar to the findings of other authors ${ }^{(4,14)}$.

Some of the cases brought forth by FHS for discussion and sharing were unknown by the teams - especially by the technicians. Knowing the case and its history to be discussed and shared with the NASF is one of the minimum requirements for integrated work between both teams. When this does not happen, the NASF becomes a virtual gateway to the system, which weakens the bond, longitudinal follow-up and completeness of healthcare provided by the FHS teams. Therefore, matricial support remains as a challenge to be achieved, which will only occur when there are family health teams "available for the NASF work" ${ }^{(15)}$.

The lack and often inefficiency of HCN services, combined with the expectation from FHS professionals that NASF will eminently perform outpatient care in order to address the health care needs of the population, create referrals and requests that do not match the NASF proposal or the care provisions for this level of care.

The impossibility of referencing a case, whether for lack of professionals in any of the services or the existence of a large repressed demand, generates overloads on NASF workers and also suffering and personal frustration in the face of requests for service, knowing that they could offer more if their work model was different, which also occurs from the user's perspective, who receive assistance that falls short of what they really need.

A lack of assistance to users and anxiety of professionals due to the lack of support from HCN for referral of more complex cases has also been observed in another study ${ }^{(15)}$, corroborating these findings. Other studies also argue that the NASF should not act as a substitute for other HCN services, serving more complex cases in PC in a purely assistance-based approach ${ }^{(4,11,16-17)}$.

Restricted articulation of the network compromises the support model provided for $\mathrm{NASF}^{(16)}$ and it is frequent and present in many contexts, which produces ethical conflicts denominated in Work Psychodynamics as ethical or moral suffering ${ }^{(18)}$, triggered by the experience of betraying oneself. "It is in this troubled context that some workers end up accepting to invest their efforts in servicing goals that their morals disapprove of ${ }^{\prime \prime}(19)$.

Another divergence between actual and prescribed work that is often counterproductive and creates suffering is related to the institutional goals and worker productivity demands from both the FHS and the NASF. In analyzing the work of the FHS and NASF, a study found that the nature of the work of these two teams presents differences related to concepts and productivity parameters, which compromises the accomplishment of shared actions of a collective nature ${ }^{(4)}$. The dichotomy between quantity and quality was also discussed by other authors, as well as the need to advance when creating new qualitative indicators based on the logic of comprehensiveness, able to measure the quality of followup and health care, and quality of life instead of illness ${ }^{(11,20)}$.

Historically and culturally, users of health services seek answers to their needs and complaints related to health in a fast, individualized, physician-centered and preferably medicinal manner. In a way, professional training also suffered this influence and health professionals often reproduce and value this form of care at the expense of promotive actions and illness prevention. Management also seeks more immediate, more visible and quantitatively significant results, based on an outpatient approach focused on complaints. Overcoming this short-sighted and curative culture by creating an expanded vision for the determinants and conditions of the health-disease process focusing on collective action and health promotion is a challenge to be faced by all PC workers.

Even considering the comprehensive model proposed by the SUS, health work continues to reproduce the hegemonic biomedical model set, which also contributes to the tensions of everyday work ${ }^{(21)}$.

The ever-present expectation that NASF 'should solve' the most complex cases that are discussed in an assistential and curative perspective is evident in the findings of this study, as well as the need to transcend biologistics and overcome the fragmented view of the individual, which has also been evidenced by other authors, by verifying that actions taken in the FHS based on the vision of the NASF were ruled by hard and little related technologies, and tied directly by care protocols ${ }^{(15)}$. Another study focusing on the NASF indicates the resistance felt by this team, very much due to the FHS teams, as a result of the outpatient model focused on demand on which the practices are commonly developed ${ }^{(22)}$.

Findings from this investigation also show suffering of NASF workers related to the profile and work overload. Only those who really identify with the proposal can remain at work, combating the stress, overload and illness which arise as the worker observes that they cannot perform all the tasks and meet all the needs arising from their work routine.

In a study on the professional skills of working in the $\mathrm{NASF}^{(20)}$, it is explicit that workers must have knowledge about public health policies and the epidemiological profile of the assisted population, as well as an ability to work in teams and communicate. Another study has also highlighted the concern with the profile at the selection time of workers for NASF, which was also present in this study, mainly because an inadequate profile compromises the dynamic of teamwork due to lack of motivation and identification with the work ${ }^{(11)}$.

Work overload was also due to high staff turnover, which compromises interaction and construction of interpersonal relationships between the teams and consequently the shared work. The great care demand and failures of HCN were also considered part of the work overload ${ }^{(17)}$, as well as dissatisfaction, suffering and exhaustion of FHS workers due to the demand of productivity goals ${ }^{(23)}$.

Although recording of information is perceived as a burden for workers, it is known that the informational continuity of care is an essential aspect of health practices, which justifies the need for constant and proper registration in the medical records so that there is no compromise of the longitudinal relationship of the teams with the families and consequently of the care quality provided ${ }^{(24)}$. Several forms of records characterized by workers as administrative activities are present in the NASF work routine as a strategy to 
give visibility to accomplished work, as well as legal guarantees. In addition, they overcome a lack of more precise and instituted qualitative tools for monitoring and evaluating. There are some qualitative indicators of group activities that are used each month by workers, in addition to those that can be built and implemented within the National Program for Improving Access and Quality in Primary Care ${ }^{(25)}$, and those suggested by the Primary Care Booklet \# 39 $9^{(1)}$.

The need for spaces dedicated to workers can reflect a lack of institutional support to these professionals. The exhaustion and existing overload in the NASF work reinforce the need to formally institute opportunities to support the workers in order to prevent suffering and illness.

\section{CONCLUSION}

An analysis of the NASF work process from the perspective of its workers shows that the performance of this team is not meeting the expectations or needs perceived by the FHS, which is reflected by a paradoxical process, despite its great potential for mobilizing and qualifying actions and interventions in the context of PC. It was possible to identify a gap and dialectical contradiction between its theoretical-ideological and ethical-political base premises and its implementation in the actual reality of health work, thus generating stress, suffering and impact on employees' quality of working life.

\section{RESUMO}

Objetivo: Analisar o processo de trabalho no Núcleo de Apoio à Saúde da Família. Método: Estudo de caso exploratório, descritivo e de abordagem qualitativa. Grupos focais foram realizados com 20 trabalhadores do Núcleo de Apoio à Saúde da Família, o material empírico foi submetido à técnica de análise de conteúdo e analisado à luz da Psicodinâmica do Trabalho. Resultados: Apresenta-se aqui a categoria sofrimento que neste estudo decorre da contradição dialética entre o trabalho real e o trabalho prescrito, da resistência à proposta do Núcleo de Apoio à Saúde da Família e da falta de compreensão de seu papel; da cultura imediatista e curativa do usuário e da Estratégia Saúde da Família; do perfil, sobrecarga e identificação com o trabalho. Conclusão: A contradição dialética entre expectativas das equipes da Estratégia Saúde da Família e o trabalho no Núcleo de Apoio à Saúde da Família compromete sua efetivação e gera sofrimento aos trabalhadores.

\section{DESCRITORES}

Estratégia Saúde da Família; Pessoal de Saúde; Trabalho; Estresse Psicológico; Qualidade de Vida.

\section{RESUMEN}

Objetivo: Analizar el proceso laboral en el Núcleo de Apoyo a la Salud de la Familia. Método: Estudio de caso exploratorio-descriptivo y de abordaje cualitativo. Grupos focales fueron realizados con 20 trabajadores del Núcleo de Apoyo a la Salud de la Familia, el material empírico fue sometido a la técnica de análisis de contenido y analizado a la luz de la Psicodinámica del Trabajo. Resultados: Se presenta aquí la categoría sufrimiento, que en este estudio es consecuente de la contradicción dialéctica entre el trabajo real y el trabajo prescrito, de la resistencia a la propuesta del Núcleo de Apoyo a la Salud de la Familia y la falta de compresión de su papel; de la cultura inmediatista y curativa del usuario y la Estrategia Salud de la Familia; del perfil, sobrecarga e identificación con el trabajo. Conclusión: Se presenta aquí la categoría sufrimiento, que en este estudio es consecuente de la contradicción dialéctica entre el trabajo real y el trabajo prescrito, de la resistencia a la propuesta del Núcleo de Apoyo a la Salud de la Familia y la falta de compresión de su papel; de la cultura inmediatista y curativa del usuario y la Estrategia Salud de la Familia; del perfil, sobrecarga e identificación con el trabajo.

\section{DESCRIPTORES}

Estrategia Salud de la Familia; Personal de Salud; Trabajo; Estrés Psicológico; Calidad de Vida.

\section{REFERENCES}

1. Brasil. Ministério da Saúde; Secretaria de Atenção à Saúde, Departamento de Atenção Básica. Núcleo de Apoio à Saúde da Família. Ferramentas para a gestão e para o trabalho cotidiano [Internet]. Brasília; 2014 [citado 2016 mar. 12]. (Cadernos de Atenção Básica, n. 39). Disponível em: http://189.28.128.100/dab/docs/portaldab/publicacoes/caderno_39.pdf

2. Brasil. Ministério da Saúde. Portaria GM nº154, de 24 de janeiro de 2008. Cria os Núcleos de Apoio à Saúde da Família - NASF [Internet]. Brasília; 2008 [citado 2016 mar.12]. Disponível em: http://bvsms.saude.gov.br/bvs/saudelegis/gm/2008/prt0154_24_01_2008.html

3. Brasil. Ministério da Saúde; Secretaria de Atenção à Saúde, Núcleo Técnico da Política Nacional de Humanização. Clínica ampliada, equipe de referência e projeto terapêutico singular [Internet]. Brasília; 2007 [citado 2016 mar.12]. Disponível em: http://bvsms.saude.gov. br/bvs/publicacoes/clinica_ampliada_2ed.pdf

4. Lancman S, Gonçalves RMA, Cordone NG, Barros JO. Estudo do trabalho e do trabalhar no Núcleo de Apoio à Saúde da Família. Rev Saúde Pública. 2013;47(5):968-75.

5. Brasil. Ministério da Saúde; Secretaria de Atenção à Saúde, Departamento de Atenção Básica. Diretrizes do NASF: Núcleo de Apoio à Saúde da Família [Internet]. Brasília; 2010 [citado 2016 fev. 19]. Disponível em: http://bvsms.saude.gov.br/bvs/publicacoes/caderno_ atencao_basica_diretrizes_nasf.pdf

6. Brasil. Ministério da Saúde. Portaria n. 3.124, de 28 de dezembro de 2012. Redefine os parâmetros de vinculação dos Núcleos de Apoio à Saúde da Família (NASF) Modalidades 1 e 2 às Equipes Saúde da Família e/ou Equipes de Atenção Básica para populações específicas, cria a Modalidade NASF 3, e dá outras providências. [Internet]. Brasília; 2012 [citado 2016 jan. 10]. Disponível em: http://bvsms.saude. gov.br/bvs/saudelegis/gm/2012/prt3124_28_12_2012.html

7. Minayo MCS. O desafio do conhecimento: pesquisa qualitativa em saúde. 14ª ed. São Paulo: Hucitec; 2014. 
8. Dejours C. Parte I: trajetória teórico conceitual; parte II: a clínica do trabalho; parte II: perspectivas. In: Lancman S, Sznelwar LI, organizadores. Christophe Dejours: da psicopatologia à psicodinâmica do trabalho. $3^{\mathrm{a}}$ ed. Brasília: Paralelo 15; 2011. p. 47-334.

9. Bardin L. Análise de conteúdo. Lisboa: Edições 70; 2011.

10. Soleman C, Martins CL. O trabalho do fonoaudiólogo no Núcleo de Apoio à Saúde da Família (NASF) - especificidades do trabalho em equipe na Atenção Básica. Rev CEFAC. 2015;17(4):1241-53.

11. Silva ATC, Aguiar ME, Winck K, Rodrigues KGW, Sato ME, Grisi SJFE, et al. Núcleos de Apoio à Saúde da Família: desafios e potencialidades na visão dos profissionais da Atenção Primária do Município de São Paulo, Brasil. Cad Saúde Pública. [Internet]. 2012 [citado 2014 nov. 15];28(11):2076-84. Disponível em: http://www.scielo.br/pdf/csp/v28n11/07.pdf

12. Brasil. Ministério da Saúde. Portaria n. 2488, de 21 de outubro de 2011. Aprova a Política Nacional de Atenção Básica, estabelecendo a revisão de diretrizes e normas para a organização da Atenção Básica, para a Estratégia Saúde da Família (ESF) e o Programa de Agentes Comunitários de Saúde (PACS) [Internet]. Brasília; 2011 [citado 2016 mar. 12]. Disponível em: http://www.brasilsus.com.br/legislacoes/ gm/110154-2488.html

13. Ellery AEL, Pontes RJS, Loiola FA. Campo comum de atuação dos profissionais da Estratégia Saúde da Família no Brasil: um cenário em construção. Physis [Internet]. 2013 [citado 2014 out. 20];23(2):415-37. Disponível em: http://www.scielo.br/pdf/physis/v23n2/v23n2a06.pdf

14. Matuda CG, Pinto NRS, Martins CL, Frazão P. Colaboração interprofissional na Estratégia Saúde da Família: implicações para a produção do cuidado e a gestão do trabalho. Cienc Saúde Coletiva [Internet]. 2015 [citado 2016 mar. 12];20(8):2511-21. Disponível em: http:// www.scielo.br/pdf/csc/v20n8/1413-8123-csc-20-08-2511.pdf

15. Oliveira PRS, Reis F, Arruda CAM, Vieira ACVC, Tófoli LF. Novos olhares, novos desafios: vivências dos Núcleos de Apoio à Saúde da Família em Fortaleza-CE. Cadernos ESP [Internet]. 2012 [citado 2014 maio 04];6(1):54-64. Disponível em: http://www.esp.ce.gov.br/ cadernosesp/index.php/cadernosesp/article/view/74

16. Cunha GT, Campos GWS. Apoio matricial e atenção primária em saúde. Saúde Soc [Internet]. 2011 [citado 2016 jan. 16];20(4):961-70. Disponível em: http://www.scielo.br/pdf/sausoc/v20n4/13.pdf

17. Leite DF, Nascimento DDG, Oliveira MAC. Qualidade de vida no trabalho de profissionais do NASF no município de São Paulo. Physis [Internet]. 2014 [citado 2016 jan. 16];24(2):507-25. Disponível em: http://www.scielo.br/pdf/physis/v24n2/0103-7331-physis-24-02-00507.pdf

18. Dejours C. A banalização da injustiça social. Rio de Janeiro: Fundação Getulio Vargas; 1999.

19. Dejours C. A sublimação, entre sofrimento e prazer no trabalho. Rev Port Psicanal [Internet]. 2013 [citado 2014 out. 20];33(2):9-28. Disponível em: http://sppsicanalise.pt/wp-content/uploads/2014/04/SUBLIMA\%C3\%87\%C3\%83O-ENTRE-SOFRIMENTO-E-PRAZER-NO-TRABALHO.pdf

20. Nascimento DDG, Oliveira MAC. Reflexões sobre as competências profissionais para o processo de trabalho nos Núcleos de Apoio à Saúde da Família. Mundo Saúde. 2010;34(1):92-6.

21. Peduzzi M, Carvalho BG, Mandú ENT, Souza GCS, Silva JAM. Integralidade do cuidado: representações sociais das equipes de Saúde da Família do Distrito Federal. Physis [Internet]. 2011 [citado 2016 jan. 16];21(2):629-46. Disponível em: http://www.scielo.br/pdf/physis/v21n2/ a15v21n2.pdf

22. Reis ML, Medeiros M, Pacheco LR, Caixeta CC. Evaluation of the multiprofissional work of the Family Health Support Center (NASF). Texto Contexto Enferm [Internet]. 2016 [cited 2016 Mar 12];25(1):e2810014. Available from: http://www.scielo.br/pdf/tce/v25n1/01040707-tce-25-01-2810014.pdf

23. Shimizu HE, Carvalho Junior DA. O processo de trabalho na Estratégia Saúde da Família e suas repercussões no processo saúde-doença. Ciênc Saúde Colet [Internet]. 2012 [citado 2016 jan. 16];17(9):2405-14. Disponível em: http://www.scielo.br/pdf/csc/v17n9/a21v17n9.pdf

24. Arce VAR, Sousa MF. Integralidade do cuidado: representações sociais das equipes de Saúde da Família do Distrito Federal. Saúde Soc [Internet]. 2013 [citado 2016 jan. 15];22(1):109-23. Disponível em: http://www.scielo.br/pdf/sausoc/v22n1/11.pdf

25. Brasil. Ministério da Saúde. Programa Nacional de Melhoria do Acesso e da Qualidade na Atenção Básica: manual instrutivo [Internet]. Brasília; 2012 [citado 2015 out. 20]. Disponível em: http://dab.saude.gov.br/sistemas/pmaq/faq.php 